\title{
Rare etiology for splenium of corpus callosum infarction
}

Anterior cerebral artery dissecting aneurysm

Xianjin Zhu, MD, Xuebin Zhang, MD, Shuo Lu, MD, and Zunjing Liu, MD

Correspondence

Neurology ${ }^{\circledR}$ 2018;91:481-482. doi:10.1212/WNL.0000000000006133

Dr. Liu

liuzunjing@163.com

Figure Anterior cerebral artery dissecting aneurysm for splenium of corpus callosum infarction
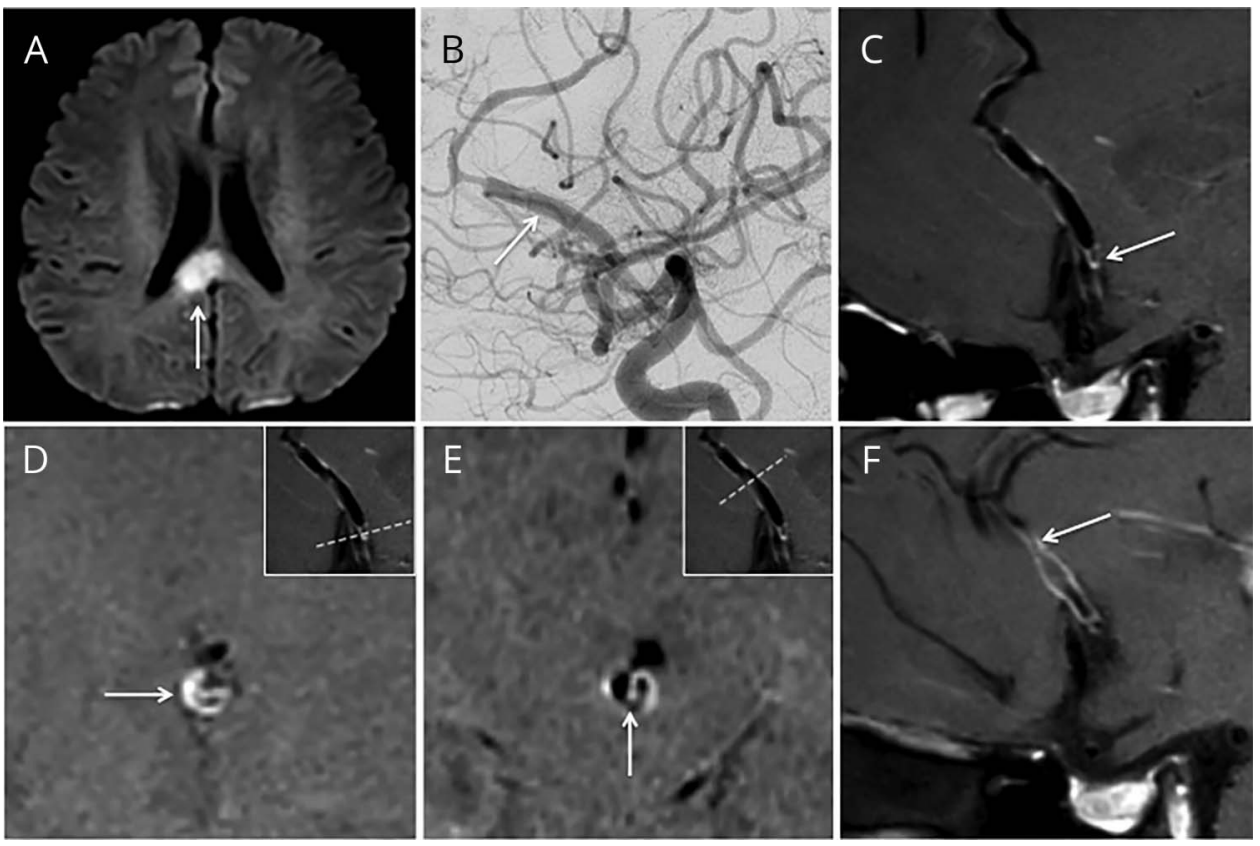

(A) Diffusion-weighted imaging shows acute infarction in the right splenium of corpus callosum. (B) Digital subtraction angiography displays dilation with stenosis lesion in the right anterior cerebral artery. Long (C, arrow) and short (D, E, arrow) axial view of high-resolution MRI reveals intimal flap indicating dissecting aneurysm. (F, arrow) Follow-up MRI detects the segmental change from luminal dilation to stenosis.

A 53-year-old man presented with left hand weakness. Brain MRI revealed acute infarction in the right splenium (figure, A) of corpus callosum. Digital subtraction angiography showed a dilation with stenosis lesion in the right $\mathrm{A} 2$ segment (figure, B) of anterior cerebral artery (ACA). 3D High-resolution MRI (HRMRI) revealed an intimal flap and double lumen sign in the ACA (figures, C-E), confirming the diagnosis of dissecting aneurysm. Follow-up HRMRI detected the segmental luminal change from dilation to stenosis (figure, F, arrow, 3 months later). The splenium is generally supplied by a branch of the posterior cerebral artery. ${ }^{1}$ ACA dissecting aneurysm is a rare etiologic mechanism. HRMRI could help achieve a definite diagnosis of dissection.

\section{Author contributions}

Xianjin Zhu: study concept and design, acquisition of data. Xuebin Zhang, Shuo Lu: acquisition of data, analysis and interpretation of data. Zunjing Liu: study concept and design, critical revision of manuscript for intellectual content. 


\section{Study funding}

Supported by the National Key Research and Development Program of China (2016YFC0103003, 2016YFC0100105), Beijing Municipal Science \& Technology Commission (Z171100001017197), and the National Natural Science Foundation of China (31771045).

\section{Disclosure}

$\mathrm{X}$. Zhu receives research support from the National Key Research and Development Program of China
(2016YFC0103003, 2016YFC0100105), Beijing Municipal Science \& Technology Commission (Z171100001017197). $\mathrm{X}$. Zhang and S. Lu report no disclosures relevant to the manuscript. Z. Liu receives research support from the National Natural Science Foundation of China (31771045). Go to Neurology.org/ $\mathrm{N}$ for full disclosures.

\section{Reference}

1. Türe U, Yaşargil MG, Krisht AF. The arteries of the corpus callosum: a microsurgical anatomic study. Neurosurgery 1996;39:1075-1084

\section{A New Generation of Fall Conference}

Register today for the 2018 Fall Conference taking place October 26 through 28 in Las Vegas and experience an enhanced and expanded program complete with some of the most popular education courses and breakthrough scientific research from the record-setting 2018 Annual Meeting.

Visit AAN.com/view/fall today.

\section{Share Your Artistic Expressions in Neurology 'Visions'}

AAN members are urged to submit medically or scientifically related artistic images, such as photographs, photomicrographs, and paintings, to the "Visions" section of Neurology ${ }^{\oplus}$. These images are creative in nature, rather than the medically instructive images published in the NeuroImages section. The image or series of up to six images may be black and white or color and must fit into one published journal page. Accompanying description should be 100 words or less; the title should be a maximum of 96 characters including spaces and punctuation.

Please access the Author Center at NPub.org/authors for full submission information.

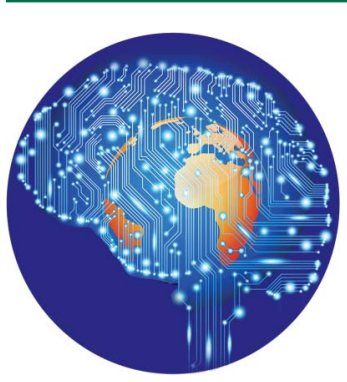

\section{Practice Current: An interactive exchange on controversial topics}

Share your own best practices.

Read commentary with expert opinion.

Explore results on an interactive world map.

NPub.org/NCP/practicecurrent

Neurology ${ }^{\circledR}$ Clinical Practice 


\section{Neurology}

\section{Rare etiology for splenium of corpus callosum infarction: Anterior cerebral artery dissecting aneurysm \\ Xianjin Zhu, Xuebin Zhang, Shuo Lu, et al. \\ Neurology 2018;91;481-482 \\ DOI 10.1212/WNL.0000000000006133}

This information is current as of September 3, 2018

Updated Information \&
Services
References
Citations
Subspecialty Collections
Permissions \& Licensing
Reprints

Updated Information \&

\section{References}

\section{Citations}

\section{Subspecialty Collections}

Reprints including high resolution figures, can be found at: http://n.neurology.org/content/91/10/481.full

This article cites 1 articles, 0 of which you can access for free at: http://n.neurology.org/content/91/10/481.full\#ref-list-1

This article has been cited by 1 HighWire-hosted articles: http://n.neurology.org/content/91/10/481.full\#\#otherarticles

This article, along with others on similar topics, appears in the following collection(s):

\section{Infarction}

http://n.neurology.org/cgi/collection/infarction

Information about reproducing this article in parts (figures,tables) or in its entirety can be found online at:

http://www.neurology.org/about/about_the_journal\#permissions

Information about ordering reprints can be found online:

http://n.neurology.org/subscribers/advertise

Neurology ${ }^{\circledR}$ is the official journal of the American Academy of Neurology. Published continuously since 1951, it is now a weekly with 48 issues per year. Copyright @ 2018 American Academy of Neurology. All rights reserved. Print ISSN: 0028-3878. Online ISSN: 1526-632X.

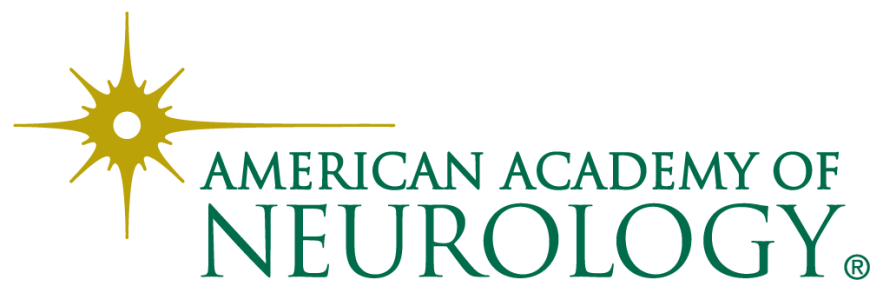

